Studia nad Autorytaryzmem i Totalitaryzmem 43, nr 2

Wrocław 2021

https://doi.org/10.19195/2300-7249.43.2.31

\author{
JUSTYNA BAZYLIŃSKA-NAGLER \\ ORCID: 0000-0002-0190-7566 \\ Uniwersytet Wrocławski \\ justyna.bazylinska-nagler@uwr.edu.pl
}

\title{
Zrównoważony rozwój w tradycji prawnej Chińskiej Republiki Ludowej
}

Slowa kluczowe: tradycja prawna, Chińska Republika Ludowa, konfucjanizm, totalitaryzm, autorytaryzm, despotyzm, zasada ogólna prawa międzynarodowego, zrównoważony rozwój.

\section{SUSTAINABLE DEVELOPMENT IN THE LEGAL HISTORY \\ OF THE PEOPLE'S REPUBLIC OF CHINA}

\begin{abstract}
An old Chinese saying says: "Nature and man joined into one whole" (Tian Ren He Yi) ${ }^{1}$. One could think that Chinese political thought, extensively bound to religion, philosophy, and tradition, laid perfect foundations for the implementation of public international law sustainable development principles. However, Chinese totalitarianism irreversibly changed the perception of the relation between humans and nature that used to be deeply rooted in traditional culture. The purpose of this work was to analyze the evolution of Chinese attitude towards sustainable development that serves environmental protection. The key issue concerning the Chinese willingness to fulfill their international obligations concerning sustainable development had to be addressed. Equally important was the question about the integration principle in Chinese law which would imply balancing environmental needs with economic development in all state politics as it does in the EU law under article 11 of the Treaty on the Functioning of the European Union. The research shows that Chinese environmental law has been notably shaped by public international law in correlation to its standards and has developed significantly for the last 35 years. A good example may be the amendment of 2014 of Chinese Environmental Law that implemented expressis verbis sustainable development as a priority before economic development. However, it seems to be a landmark change, opening new research fields considering its future execu-
\end{abstract}

${ }^{1}$ W. Hou, Reflections on Chinese traditional views of nature, „Environmental History” 2, 1997, s. 1. 
tion. Considering the above, this work concludes with some moderate but ironic optimism linked to the current plan of the People's Republic of China to build „ecological civilization.”

Keywords: legal tradition, the People's Republic of China, Confucianism, Chinese totalitarianism, authoritarianism, despotism, general principle of public international law, sustainable development.

\section{1. Środowisko naturalne w chińskiej tradycji prawnej}

Oficjalną doktryną Chin ${ }^{2}$, jednego z największych i najludniejszych państw świata, przez ponad dwa tysiące lat był konfucjanizm. Sfera jego wpływów wykraczała daleko poza ojczyste Chiny. To właśnie konfucjanizm, jako system filozoficzny kładący szczególny nacisk na normy życia społecznego, na etykę i moralność, ukształtował w znacznej mierze moralno-etyczne oblicze Azji Wschodniej.

Konfucjusz mawiał, że „aby ujrzeć przyszłość, trzeba uchwycić przeszłość”3. W ujęciu historycznym, u zarania tradycji politycznych Chin leży ukształtowana tam szczególnego typu organizacja polityczna zwana „państwem konfucjańskim”. Jego podstawowe założenia wypracowane zostały w szkole Konfucjusza (555-479 p.n.e.), a po utworzeniu cesarstwa, za panowania cesarza Wudi (140-87 p.n.e.), stały się oficjalną ideologią. Starożytne konfucjańskie tradycje polityczne kładły nacisk na wyższość grupy nad jednostką. Przedkładały szacunek do władzy ponad swobody. Podkreślały, że odpowiedzialność jest ważniejsza od praw. W społeczeństwach konfucjańskich prawa jednostki jako przyrodzone człowiekowi nie istniały. Mogły natomiast być nadawane przez państwo. Zupełnie brakowało tam tradycji uznawania praw jednostki do obrony przed państwem. Największymi wartościami były ład społeczny i poszanowanie hierarchii. Stąd brało się usilne dążenie do zachowania harmonii i współpracy, a także bezwzględne potępienie dla sporów i konkurencji ${ }^{4}$. Wszelkie przejawy konfliktu, czy to na poziomie idei, grup, czy partii, postrzegano

${ }^{2}$ Chińska myśl polityczna, jak myśl żadnej innej cywilizacji, jest głęboko związana z religią i filozofią. W swych podstawach zachowała ciągłość od czasów „mitycznego cesarstwa” (około XXII wieku p.n.e.) aż do przełomu XIX i XX wieku. Legendarnym myślicielem z okresu „stu szkół" (770-221 p.n.e.) był Lao-tsy, któremu przypisuje się autorstwo dzieła Tao Te Ching (Droga i jej potęga). W wiekach późniejszych interpretacje myśli Lao-tsy doprowadziły do wykształcenia się kościoła taoistycznego (II wiek n.e). Tao to droga, porządek istniejący w przyrodzie i w niebie, który powinien odnaleźć pełne odzwierciedlenie w „tao” człowieka. Szerzej zob. W. Bernacki, Chińska myśl polityczna, [hasło w:] Stownik historii doktryn politycznych, red. M. Jaskólski, t. 1, Warszawa 1997, s. 351-358; Encyklopedia mądrości Wschodu: buddyzm, hinduizm, taoizm, zen, red. I. Fischer-Schreiber, przeł. M.J. Künstler, Warszawa 1997.

3 Konfucjusz, Dialogi, przeł. K. Czyżewska-Madajewicz, M.J. Kunstler, Z. Tłumski, Wrocław 1976.

${ }^{4} \mathrm{~K}$. Gawlikowski, The Western and the Confucian approaches to war: The universe based on struggle versus the universe based on harmony, [w:] China: Confucian Tradition - Towards the New Century, red. A.W. Jelonek, B.S. Zemanek, Kraków 2008, s. 19-40. 
jako niebezpieczne i bezprawne $e^{5}$. Ten specyficzny typ państwa funkcjonował w Chinach mimo rozmaitych przemian, przez ponad dwa tysiące lat, a jeśli doliczyć okres jego formowania, jeszcze przed Konfucjuszem, to można mówić nawet o tradycjach politycznych ${ }^{6}$ sięgających ponad trzech tysiącleci ${ }^{7}$. System ten organizował życie zbiorowości ludzkich Południowo-Wschodniej Azji, w starożytności tak licznych jak Imperium Rzymskie, liczniejszych nawet od późniejszych państwowości w całej Europie. Był to jedyny starożytny twór prawo-polityczny, który przetrwał aż do początków XX wieku. Profesor Krzysztof Gawlikowski nazywał państwo konfucjańskie najtrwalszym systemem politycznym w dziejach ludzkości, obejmującym przez tysiąclecia ogromne obszary i największą liczbę obywateli ${ }^{8}$.

Tradycje polityczno-prawne państw konfucjańskich ${ }^{9}$ były zasadniczo odmienne od tradycji politycznych Zachodu, wywodzących się z dziedzictwa grecko-rzymskiego, czy też ze źródeł judeochrześcijańskich rozwijających się w basenie Morza Śródziemnego i w Europie ${ }^{10}$. W kręgu cywilizacji konfucjańsko-buddyjskiej, tradycyjne formy państwowości przetrwały w szczególnie szerokim zakresie. Państwa takie jak Chiny, Korea, Japonia czy Wietnam formowały się stosunkowo wcześnie i miały niezwykle rozbudowane struktury biurokratyczne, a ciągłość państwowa była w nich zachowana od starożytności aż do XX wieku. Procesy modernizacji przebiegały tam różnie, zależnie od charakteru miejscowych instytucji politycznych i tradycji kulturowych, które jednak wciąż zachowują tam mniejsze bądź większe znaczenie. $Z$ czasem stworzono instytucje prawne typu zachodniego ${ }^{11}$, najpierw pod

5 S.P. Huntington, Democracy's third wave, ,Journal of Democracy” 2, 1991, nr 2, s. 24.

6 Tradycja (łac. traditio — przekaz, od tradere — przekazywać) w podstawowym rozumieniu oznacza „po prostu całokształt związków teraźniejszości z przeszłością”. Za: J. Szacki, Tradycja, Warszawa 2011, s. 37; „Trudno jest przyjąć jakąkolwiek definicję w pełni zadowalającą socjologów, historyków [...], prawników czy politologów, a więc spełniającą jednocześnie nie tylko ich szczególne wymagania, lecz i formułowane przez nich kryteria ścisłości naukowej [...] Próba wyzwolenia się od tradycji jako legitymizacji idei politycznych poprzez ich dawność, promowana przez myślicieli i ideologów podważających jej role z racji wyznawanego historyzmu i stopniowego zastępowania jej długotrwałym procesem historycznym, jak w przypadku K. Marksa, natrafiła na barierę konieczności poszukiwania »postępowych tradycji« dla wywiedzenia antecedencji ich tez historycznych [...] Siłą tradycji jest »dawność« jako wartość samoistna, niewymagająca uzasadnienia i zarazem na swój sposób samokreująca [...] Tradycja jest zjawiskiem i bytem społeczno-kulturowym o neutralnym zabarwieniu, pod warunkiem, że jest badana metodami naukowymi”. Za: M. Jaskólski, Tradycja [hasło w:] Stownik historii doktryn politycznych, t. 6, red. K. Chojnacka, M. Jaskólski, Warszawa 2015, s. 171-176.

${ }^{7}$ K. Gawlikowski, Konfucjański model państwa w Chinach, Warszawa 2009, s. 7.

8 Ibidem.

9 Wzorce i założenia modelu państwa konfucjańskiego przyjmowano w krajach ościennych takich jak: Wietnam, Korea i Japonia, a także w przejściowych formach państw: tanguckiego, kitańskiego, dżurdżeńskiego, mandżurskiego, Bohai czy też w sinitycznej Mongolii. K. Gawlikowski, Konfucjański model państwa..., s. 8 n.

${ }^{10}$ Ibidem, s. 9.

11 Przykładowo, współcześnie w zakresie tak zwanej demokracji środowiskowej wprowadzono: prawo do informacji o stanie środowiska oraz prawo partycypacji społecznej w decyzjach ma- 
wpływem mocarstw kolonialnych ${ }^{12}$, później także recypując standardy prawa międzynarodowego publicznego ${ }^{13}$. Instytucje te przyjęły formy hybrydalne, mieszając się z tradycyjnymi wzorami lokalnymi, lub nadal występują w swej historycznej postaci, przy niewielkich tylko adaptacjach do potrzeb współczesnych.

Życie człowieka w harmonii z naturą (Ziemią) ${ }^{14}$ było podstawowym założeniem chińskich nurtów filozoficzno-religijnych i zarazem doktryn politycznych, takich jak: taoizm, konfucjanizm, buddyzm, czy nawet chińskie tradycje ludowe ${ }^{15}$. Gloryfikowały one stan równowagi, człowiek powinien zachowywać harmonię

jących wpływ na środowisko. Por. X. Zhu, K. Wu, Public participation in China's environmental lawmaking: In pursuit of better environmental democracy, ,Journal of Environmental Law” 29, 2017. Wzorce zachodnie w Chinach nie są jednak traktowane jako oczywiście słuszne i dobre. Dyskusja o demokracji wywołuje wspomnienie bolesnych doświadczeń historycznych — lat dwudziestych XX wieku, gdy próbowano wprowadzać demokrację parlamentarną, która doprowadziła kraj do skrajnej nędzy i upadku, czy też „rewolucji kulturalnej” lat sześćdziesiątych XX wieku, gdy każdy mógł organizować protesty uliczne, strajki, wywieszać na ulicach propagandowe gazetki. Obecnie chińska konstytucja nie przewiduje prawa do strajku czy swobodnych protestów ulicznych.

12 Do 1899 roku największą strefą wpływów państw zachodnich w Azji była strefa wokół doliny rzeki Jangcy, obejmująca niemal jedną trzecią obszaru Cesarstwa Chińskiego, należąca do Brytyjczyków. Strefy takie utworzyły też Niemcy, Francja, Rosja i Japonia. Por. Doc. No 1898/1, Great Britain and China. Declaration concerning the non-alienation of the Yang-tsze region, February 11, 1898, [w:] Treaties and Agreements with and Concerning China 1894-1919, [w:] Treaties and Agreements with and Concerning China 1894-1919, red. J.V.A. MacMurray, t. 1. Manchu Period (1894-1911), Oxford-New York 1921, s. 104-105; Doc. No 1899/3, Great Britain and Russia, [w:] ibidem, s. 204. Por. J. Pajor, Wielka Brytania wobec kształtowania się amerykańskiej polityki „Otwartych drzwi” w Chinach (1898-1900), „Acta Universitatis Lodziensis Folia Historica” 89, 2012, s. 8; W. Rojek, Ekspansja mocarstw w Chinach i jej wpływ na rozwój stosunków międzynarodowych w latach 1895-1914, Kraków 1990, s. 24.

13 E.Y.J. Lee, Early development of modern international law in East Asia - with special reference to China, Japan and Korea, „Journal of the History of International Law” 4, 2002, s. 45-46.

14 Założenie, że Niebo i Ziemia są ojcem i matką wszystkich stworzeń, w tym oczywiście ludzi, formułowano jeszcze w starożytności, ale rozwinęli i upowszechnili te idee dopiero neokonfucjaniści. W sławnej Inskrypcji zachodniej (Xi ming, 西銘) Zhang Zaia, 張載 (1020-1077) jednego z twórców neokonfucjanizmu, stwierdza się: „Niebo jest moim ojcem, a Ziemia jest moją matką. Nawet tak drobna istota jak ja znajduje bezpieczne miejsce między nimi. Dlatego to, co wypełnia uniwersum, uznaję za swoje ciało, a to, co kieruje uniwersum (czyli wolę Nieba i Ziemi), uznaję za swoją naturę. Wszyscy ludzie są moimi braćmi i siostrami, a wszystkie byty są moimi towarzyszami" - za: K. Gawlikowski, Zachodni indywidualizm a konfucjańska apoteoza wspólnoty i tożsamości grupowej, „Azja-Pacyfik” 23, 2020, s. 41.

15 Tradycjonalizm (od łac. traditio - przekaz), ,w pierwszym znaczeniu to postawa społeczna wyrażająca szczególne przywiązanie do tradycji i związanych z nią wartości [...]. W drugim znaczeniu tradycjonalizm dotyczy tych idei i doktryn politycznych, które zbudowano na fundamencie tradycji. Wbrew pozorom nie jest to fundament ani jednolity, ani jednorodny, ani też pozbawiony wewnętrznych sprzeczności" — za: M. Jaskólski, Tradycjonalizm, [w:] Słownik..., s. 176-178; J. Szacki wskazał na następujące cechy tak zwanego tradycjonalizmu integralnego charakterystycznego dla okresu przedpiśmiennego, a potem dla znacznej części myślenia przedkapitalistycznego: 1. wyraźne zabarwienie religijne i sakralizacja przeszłości; 2. przyjęcie boskiego (naturalnego) porządku świata, a więc przyrody, obyczaju, prawa; 3. niezmienność tego porządku, dopuszczalność katastrof, lecz nie zmian; 4. zintegrowanie kultury jako całości i objęcie społeczną kontrolą całego życia jednostek; 5. bezalternatywność tego światopoglądu. J. Szacki, Tradycja..., s. 192-193.

Studia nad Autorytaryzmem i Totalitaryzmem 43, nr 2, 2021

(C) for this edition by CNS 
psycho-fizyczną, zgodę w stosunkach z rodziną i z innymi ludźmi, a także z przyrodą. Powinien czuć się integralną częścią swojego naturalnego środowiska.

Zrównoważone korzystanie z zasobów przyrody, było nie tylko powszechnie stosowane w starożytnej filozofii Wschodniej Azji, ale też uznawane przez wielu badaczy za klucz do jej sukcesu ${ }^{16}$. Karl August Wittfoge ${ }^{17}$, historyk i badacz systemu politycznego Chin, w swojej pracy Władza totalna: studium porównawcze despotyzmu wschodniego ${ }^{18}$ przedstawił analizę społeczeństwa orientalnego, mechanizmów władzy oraz azjatycką teorię sposobu produkcji w tak zwanym państwie hydraulicznym ${ }^{19}$. Teoria ta wyrasta $\mathrm{z}$ przekonania o zasadniczym wpływie czynników przyrodniczych na ukształtowanie systemu agromenadżerskiego despotyzmu w krajach Wschodu. Wittfogel wykazał, że im bardziej umacniały się systemy despotyczne, tym mniej zrównoważone stawało się gospodarowanie (rolnictwo) ich społeczeństw. Despotyczna forma rządów, władza elit wiązała się bowiem z chęcią zysku, nadmierną akumulacją kapitału i dewastacją zasobów naturalnych. Brak szacunku dla przyrody powodował katastrofy naturalne i ostatecznie przyczyniał się do upadku starożytnych despotycznych mocarstw ${ }^{20}$.

\section{Zasady zrównoważonego rozwoju uznane przez narody cywilizowane}

Podstawowe założenia prawa międzynarodowego w dzisiejszym rozumieniu tego pojęcia mają swoje źródło w rozwoju kultury i organizacji politycznej Zachodu. Prawo narodów zapuściło swoje korzenie i rozwijało się wraz z nauką renesansowej Europy, jego początki mają jednak o wiele szerszy rodowód i sięgają daleko w przeszłość. Po okresie lekceważenia, obecnie większym szacunkiem darzy się kultury i wartości, które powstały i rozwinęły się przed narodzeniem Chrystusa na Dalekim Wschodzie w ramach cywilizacji hinduskiej ${ }^{21}$ i chińskiej ${ }^{22}$. Wiele ówczesnych

${ }^{16}$ E. Benvenisti, Asian traditions and contemporary international law on the management of natural resources, „Chinese Journal of International Law” 7, 2008, s. 279 n.

17 M. Albińska, Karl August Wittfogel: badacz tradycji władzy totalnej w dziejach cywilizacji, Toruń 2006.

18 K.A. Wittfogel, Władza totalna: studium porównawcze despotyzmu wschodniego, Toruń 2004.

19 Do cywilizacji rzecznych starożytnego świata zaliczamy: Chiny starożytne w dolinie Huang-ho, miasta Mohendżo-Daro i Harappa w dolinie Indusu, państwa powstałe w Mezopotamii wzdłuż Eufratu i Tygrysu, Egipt starożytny wzdłuż Nilu.

20 E. Benvenisti, op. cit., s. 279-280.

21 N. Singh, The distinguishing characteristics of the concept of the Law of Nations as it developed in ancient India, [w:] Liber Amicorum for Lord Wilberforce, red. A. Bos, I. Brownlie, Oxford 1987, s. 91.

22 I.C.Y. Hsu, China's Entrance into the Family of Nations, Harvard, 1960; K. Iriye, The principles of international law in the light of Confucian doctrine, „Recueil des Cours” 120, 1967, s. 1; E.Y.J. Lee, op. cit., s. 42. 
hinduskich norm było dowodem wzrastającego w tych społecznościach poczucia moralności. Cesarstwo Chińskie natomiast poświęciło sporo uwagi harmonijnym relacjom między jego warstwami społecznymi. Można tu wskazać wiele zasad, które przetrwały do dziś jako ważne elementy porządku międzynarodowego ${ }^{23}$.

Zrównoważony rozwój jest szczególnym zjawiskiem prawa międzynarodowego. Jego normatywna postać nie została dotychczas jednoznacznie określona ani w przepisach prawa, ani w jurysprudencji i doktrynie. W języku prawniczym posługujemy się „,pojęciem zrównoważonego rozwoju” (sustainable development concept ${ }^{24}$ albo mówimy o „zasadach zrównoważonego rozwoju” (sustainable development principles ${ }^{25}$, sugerując, że jest to swoisty konglomerat zasad prawa międzynarodowego (sub-principles of sustainable development). Niezbyt często, ale jednak pojawia się w literaturze ,zasada zrównoważonego rozwoju” (sustainable development principle $)^{26}$, a już zupełnie nowatorskie jest ujęcie „prawa do zrównoważonego rozwoju" (right to sustainable development) ${ }^{27}$.

Wykorzystanie w odniesieniu do zrównoważonego rozwoju pojęcia ogólnej zasady prawa w rozumieniu art. 38 ust. 1 lit. c Statutu Międzynarodowego Trybunału Sprawiedliwości ${ }^{28}$ wymaga spełnienia przesłanek właściwych dla tego przepisu. Statut mówi o trzecim, odrębnym od umowy i zwyczaju międzynarodowego

23 M.N. Shaw, Prawo międzynarodowe, Warszawa 2006, s. 34-35.

24 S.R.W. van. Hees, Sustainable development in the EU: Redefining and operationalizing the concept, „Utrecht Law Review” 10, 2014, nr 2; M. Kenig-Witkowska, The concept of sustainable development in the European Union Policy and Law, ,Journal of Comparative Urban Law and Policy" 1, 2017, nr 1.

25 Sustainable Development Principles in the decisions of International Courts and Tribunals 1992-2012, red. M.C. Cordonier Segger, C.G. Weeramantry, New York 2017, s. 35; Intergenerational Justice in Sustainable Development Treaty Implementation: Advancing Future Generations Rights through National Institutions (Treaty Implementation for Sustainable Development), red. M.C. Cordonier Segger, M. Szabo, A. Harrington, Cambridge 2021; M.C. Cordonier Segger, A. Khalfan, Sustainable Development Law: Principles, Practices, and Prospects, Oxford 2011; S. Dresner, The Principles of Sustainability, London 2008; S. Fulton, A. Benjamin, Foundations of sustainability, „The Environmental Forum”28, 2011; L.A. Avilés, Sustainable development and the legal protection of the environment in Europe, „Sustainable Development Law \& Policy” 12, 2012, nr 3, s. 30 .

${ }^{26}$ M. Humphreys, Sustainable Development in the European Union: A General Principle, London-New York 2020.

27 C. Shall, Public interest litigation concerning environmental matters before human rights courts: A promising future concept, ,Journal of Environmental Law” 20, 2008, nr 3; J. BazylińskaNagler, Right to clean environment - a warrant of sustainable development?, „Ekonomia - Wroclaw Economic Review" 24, 2018, nr 3, s. 4.

28 Artykuł 38: „Źródła prawa stosowane przez MTS przy orzekaniu: 1. Trybunał, którego zadaniem jest orzekać na podstawie prawa międzynarodowego w sporach, które będą mu przekazane, będzie stosował: a) konwencje międzynarodowe, bądź ogólne, bądź specjalne, ustalające reguły, wyraźnie uznane przez państwa spór wiodące; b) zwyczaj międzynarodowy, jako dowód istnienia powszechnej praktyki, przyjętej jako prawo; c) zasady ogólne prawa, uznane przez narody cywilizowane; d) z zastrzeżeniem postanowień art. 59 związanie wyrokiem, wyroki sądowe tudzież zdania najznakomitszych znawców prawa publicznego różnych narodów, jako środek pomocniczy do stwierdzania przepisów prawnych. 2. Postanowienie niniejsze nie stanowi przeszkody, aby Try- 
źródle prawa międzynarodowego — o „zasadach ogólnych prawa, uznanych przez narody cywilizowane". Analiza tego przepisu doprowadza wielu przedstawicieli nauki do konkluzji powodującej rozdzielenie znaczenia ogólnych zasad prawa, odrębnie w stosunkach wewnętrznych i międzynarodowych. Już samo to twierdzenie jest wystarczające, aby nie traktować ogólnych zasad prawa jako zasad prawa międzynarodowego, gdyż te ostatnie wynikają z umów międzynarodowych i międzynarodowego prawa zwyczajowego ${ }^{29}$. Ogólne zasady prawa to takie, które często mają rodowód sięgający czasów starożytnych ${ }^{30}$. Realnie obowiązują one w systemach prawnych większości państw. Zdaniem profesora Ludwika Ehrlicha:

Wskazanie na ogólne zasady prawa uznane przez narody cywilizowane [w art. 38 Statutu MTS-u - J.B.N.] zapobiec miało, w myśl intencji autorów projektu Statutu możliwości stwierdzenia w konkretnym przypadku, że Trybunał, wobec braku norm obowiązujących, nie może sporu rozstrzygnąć (non liquet). Szło więc [...] o umożliwienie Trybunałowi ustalenia, że w danym przypadku obowiązują takie normy, których wprawdzie dotychczas, ani wyraźnie nie przyjęto, ani też nie ustalono ich jako norm prawa międzynarodowego, które jednak wynikają z ogólnych zasad prawa uznanych przez narody cywilizowane, a więc pośrednio już przyjęte przez te narody. Przez zastosowanie takiej zasady w konkretnym przypadku Trybunał ustala, że norma określająca konsekwencje danych faktów na podstawie tej zasady jest normą prawa międzynarodowego, tworzy więc precedens. Warunkiem jednak zastosowania tej zasady w celu ustalenia tej nowej normy jest nie tylko to, aby była „ogólną zasadą prawa”, lecz także aby była ogólnie uznana za taką przez państwa cywilizowane ${ }^{31}$.

Niezaprzeczalnie ramy proceduralne zrównoważonego rozwoju zostały zakreślone przez sądy i trybunały międzynarodowe. Najbardziej znanym orzeczeniem w tej sprawie było Gabčikovo-Nagymaros z 1997 roku Międzynarodowy Trybunał Sprawiedliwości rozstrzygnął wtedy spór pomiędzy Węgrami a Słowacją dotyczący wykorzystania rzeki Dunaj ${ }^{32}$. Trybunał przeanalizował, czy

bunał mógł orzekać ex aequo et bono, o ile strony na to zgadzają się". Statut Międzynarodowego Trybunału Sprawiedliwości, Dz.U. z 1947 r. Nr 23, poz. 90.

29 A. Peretiatkowicz, Ogólne zasady prawa jako źródło prawa międzynarodowego a tendencje kosmopolityczne, Poznań 1956, s. 3-4.

30 L. Antonowicz, Podręcznik prawa międzynarodowego, Warszawa 1998, s. 31. Przykładowo: lex retro non agit (prawo nie działa wstecz); nemo iudex in causa sua (nikt nie może być sędzią we własnej sprawie); nemo plus iuris in alium transféré potest quam ipse habet (nikt nie może przekazać komuś więcej praw, niż sam posiada); nullum crimen sine lege (nie ma przestępstwa bez ustawy); audiatur et altera pars (należy wysłuchać również drugiej strony).

31 L. Ehrlich, Prawo międzynarodowe, Warszawa 1958, s. 25-26.

32 MTS, Gabčíkovo-Nagymaros Project (Hungary v. Slovakia), wyrok z 25 września 1997 roku, I.C.J Reports 1997, s. 7. Spór między Węgrami a Słowacją dotyczył jednostronnego zerwania przez Węgry umowy z 1977 roku o budowę dużego kompleksu hydroenergetycznego Gabčíkovo-Nagymaros. Samodzielne ukończenie przez Słowację tej inwestycji doprowadziło do zmiany biegu granicy między państwami, którą wyznaczał główny nurt rzeki, oraz do skierowania większości przepływu wody do kanału bocznego, co miało poważne skutki ekologiczne w dolinie rzeki. Międzynarodowy Trybunał Sprawiedliwości w Hadze, który orzekał na wniosek Węgier w 1997 roku przyznał Słowacji prawo budowania zapory samodzielnie, ale bez prawa ograniczania ilości wody spływającej do Węgier.

Studia nad Autorytaryzmem i Totalitaryzmem 43, nr 2, 2021

(C) for this edition by CNS 
Węgry miały prawo jednostronnie wypowiedzieć traktat bilateralny z 1977 roku. Zgodnie z art. 56 Konwencji Wiedeńskiej o Prawie Traktatów ${ }^{33}$ mogło to mieć miejsce jedynie na podstawie przesłanek uwzględnionych $\mathrm{w}$ konwencji. Jedną z tych, na które powołały się Węgry, było powstanie nowych norm międzynarodowego prawa ochrony środowiska ${ }^{34}$. I chociaż ostatecznie przesłanka ta nie została uwzględniona jako podstawa wygaśnięcia traktatu ${ }^{35}$, to Trybunał wskazał na szereg zasad, norm międzynarodowego prawa ochrony środowiska, których przestrzeganie warunkuje zrównoważony rozwój. Są to: zasada ostrożności, odpowiedzialności odszkodowawczej, estopelu, a także obowiązek dokonywania ciągłej oceny wpływu (umowy międzynarodowej) na środowisko ${ }^{36}$. W decyzji tej Międzynarodowy Trybunał Sprawiedliwości po raz pierwszy odniósł się expressis verbis do pojęcia zrównoważonego rozwoju:

Od wieków ludzkość z przyczyn ekonomicznych lub innych nieustannie ingeruje w przyrodę. W przeszłości działo się to często bez rozważania skutków tych ingerencji dla środowiska. Rozwój nauki i wzrastająca świadomość ryzyka jakie niesie za sobą dla obecnych i przyszłych pokoleń nieustanne i z niesłabnącą siłą ingerowanie w przyrodę przyczyniły się do powstania w ciągu ostatnich dwóch dekad nowych norm i standardów wyrażonych w ogromnej liczbie instrumentów prawnych. Te nowe normy i nowe standardy należy wziąć pod rozwagę, nie tylko kiedy państwa podejmują nowe aktywności, ale także w odniesieniu do przedsięwzięć podjętych w przeszłości. Tę potrzebę pogodzenia rozwoju gospodarczego z ochroną środowiska trafnie wyraża pojęcie zrównoważonego rozwoju. Dla potrzeb rozpatrywanej tutaj sprawy oznacza to, że Strony powinny wspólnie, na nowo przeanalizować skutki środowiskowe projektu elektrowni wodnej Gabčíkovo-Nagymaros. W szczególności powinny znaleźć zadowalające rozwiązanie w odniesieniu do ilości wody, która powinna płynać starym korytem Dunaju i dopływami tej rzeki po obydwu jej stronach ${ }^{37}$.

W tym samym duchu i czasie Międzynarodowy Trybunał Sprawiedliwości wypowiedział się na temat międzypokoleniowej solidarności w swojej opinii doradczej z 1996 roku w sprawie legalności użycia broni jądrowej wydanej na wniosek Zgromadzenia Ogólnego ONZ:

Środowisko nie jest jakąś abstrakcją, lecz stanowi przestrzeń życiową oraz decyduje o jakości życia i zdrowia istot ludzkich, w tym przyszłych pokoleń. Ogólny obowiązek zagwarantowania, iż działania podejmowane przez państwa w ramach ich jurysdykcji i kontroli przebiegają z poszanowaniem środowiska innych państw oraz obszarów nie podlegających

33 Konwencja wiedeńska o prawie traktatów, sporządzona w Wiedniu dnia 23 maja 1969 roku, Dz.U. z 1990 r. Nr 74, poz. 439; Konwencja wiedeńska o prawie umów międzynarodowych, przeł. i oprac. S.E. Nahlik. Warszawa 1971.

34 Sprawa Gabčikovo-Nagymaros, pkt 92, 111-114.

35 Artykuł 64: „Powstanie nowej imperatywnej normy powszechnego prawa międzynarodowego (ius cogens): Jeżeli powstanie nowa imperatywna norma powszechnego prawa międzynarodowego, jakikolwiek istniejący traktat sprzeczny z tą normą staje się nieważny i wygasa".

36 C. Cepelka, The dispute over the Gabčikovo-Nagymaros systems of locks is drawing to a close, „Polish Yearbook of International Law” 20, 1993, s. 63-74.

37 Sprawa Gabčíkovo-Nagymaros, pkt. 140 [przeł. i wyr. - J.B.N.]. 
kontroli państwowej, jest obecnie częścią całokształtu prawa międzynarodowego dotyczącego środowiska ${ }^{38}$.

W decyzji w sprawie Gabčikovo-Nagymaros Trybunał wypowiedział się zgodnie $\mathrm{z}$ duchem czasu i powszechnie uznawanym przesłaniem Raportu Brundtland ${ }^{39}$, w którym zrównoważony rozwój zdefiniowano jako „rozwój, który zaspokaja potrzeby obecnych pokoleń, bez uszczerbku dla potrzeb przyszłych pokoleń”40. Jednak wbrew oczekiwaniom przedstawicieli doktryny, MTS nie zajął jednoznacznego stanowiska $\mathrm{w}$ kwestii charakteru normatywnego zrównoważonego rozwoju. Komentatorzy podkreślali co prawda, że Trybunał użył zrównoważonego rozwoju jako zasady prawa — do kontroli spornej umowy międzynarodowej zawartej pomiędzy Węgrami a Czechosłowacją, jednak jest to wciąż zagadnienie dyskusyjne ${ }^{41}$.

$\mathrm{Z}$ tego powodu wiceprezes Trybunału, lankijski sędzia Christopher Weeramantry przygotował opinię odrębną do orzeczenia w sprawie Gabčikovo-Nagymaros, w której przedstawił zrównoważony rozwój jako jedną zasadę międzynarodowego prawa ochrony środowiska ${ }^{42}$. Zasada ta, zdaniem Weeramantry'ego, jest syntezą: prawa do rozwoju i prawa do ochrony środowiska ${ }^{43}$. Wskazał on, że jej źródła sięgają zasad życia społecznego i praktyk religijnych najstarszych azjatyckich cywilizacji rzecznych. Uważał te reguły za uprawnione źródło materialne współczesnego międzynarodowego prawa ochrony środowiska. W dążeniu do zdefiniowania pojęcia zrównoważonego rozwoju sędzia Weeramantry zbadał zasady funkcjonowania starożytnych cywilizacji opartych na nawadnianiu dolin wielkich rzek, najpierw na Sri Lance, a następnie w państwach Azji Południowo-Wschodniej. Wskazał na liczne przykłady dobrej współpracy sąsiadujących społeczności w Chinach, Kambodży, Indiach, Indonezji, Iranie i dalej na Środkowym Wschodzie w zakresie wspólnego zarządzania zasobami naturalnymi. Lokalne normy społeczne, wspólna kultura czy też religia stanowiły uzasadnienie dla zrównoważonego, długoterminowego i sprawiedliwego wykorzystywania zasobów

38 MTS, Opinia doradcza z 8 lipca 1996 roku, I.C.J Reports 1996, s. 16, § 29 [przeł. i wyr. - J.B.N.].

39 Report of the World Commission on Environment and Development: "Our Common Future", 4.08.1987 (A/42/427, Annex), https://sustainabledevelopment.un.org/content/documents/5987ourcommon-future.pdf (dostęp: 24.06.2021).

40 „1. Sustainable development is development that meets the needs of the present without compromising the ability of future generations to meet their own needs. It contains within it two key concepts: the concept of 'needs', in particular the essential needs of the world's poor, to which overriding priority should be given; and the idea of limitations imposed by the state of technology and social organization on the environment's ability to meet present and future needs". Ibidem.

41 J. Bazylińska-Nagler, op. cit., s. 4 oraz literatura tam cytowana.

42 Separate Opinion of vice-president Weeramantry w sprawie Gabčíkovo-Nagymaros Project (Hungaryv. Slovakia), https://www.icj-cij.org/public/files/case-related/92/092-19970925-JUD-01-03-EN.pdf (dostęp: 15.04.2021).

43 Ibidem, s. 91. 
wodnych $^{44}$. W odniesieniu do historycznych zasad zrównoważonego gospodarowania zasobami wodnymi w Chinach sędzia Weeramantry odwołał się do monumentalnej pracy Josepha Needhama - Science and Civilization in China ${ }^{45}$ na temat wszelkich aspektów prowadzenia prac irygacyjnych w starożytnych Chinach.

Christopher Weeramantry uważał też, że kształtujące się zasady międzynarodowego prawa ochrony środowiska znajdują oparcie w systemie filozoficzno-etycznym buddyzmu ${ }^{46}$. Cytując buddyjskie kazanie z III wieku p.n.e. zapisane w Wielkiej Kronice Sri Lanki z IV wieku n.e. zwanej Mahavamsa ${ }^{47}$, Weeramantry wskazał, że to kazanie ${ }^{48}$ zawiera pierwszą zasadę nowożytnego prawa ochrony środowiska - zasadę powiernictwa zasobów naturalnych. Jej wykładnia, skorelowana znaczeniowo $\mathrm{z}$ anglosaską doktryną zaufania publicznego (public trust doctrine ${ }^{49}$ ) pozostała aktualna przez ponad dwadzieścia stuleci. Doktryna zaufania publicznego, szczególnie popularna w państwach systemu common law, opiera się na założeniu, że tytuł prawny do zasobów środowiska naturalnego ma administracja państwowa, natomiast prawowitym właścicielem, na zasadach słuszności (equitable ownership), jest naród. Państwo jako powiernik jest

44 Wiele systemów irygacyjnych, a także układów społecznych, które im towarzyszyły, przetrwało do dnia dzisiejszego. W czasach współczesnych stały się one niepopularne, gdyż rządy państw azjatyckich pod wpływem naukowców świata Zachodu, krytycznych wobec tych „prymitywnych praktyk", zrezygnowały z rodzimych systemów na rzecz centralnie planowanego i niezrównoważonego zarzadzania zasobami wodnymi na wzór zachodni. Obecnie rozczarowane rządy państw azjatyckich, przy wsparciu nauki, starają się powrócić do tych starożytnych praktyk i wprowadzać je na nowo tam, gdzie jest to możliwe. Dotyczy to zarządzania zasobami wodnymi takich rzek jak Indus, Ganges, czy Mekong. Por. E. Benvenisti, op. cit.; C.G. Weeramantry, Tread Lightly on the Earth. Religion, the Environment and the Human Future, Pannipitiya 2014.

45 Science and Civilization in China, t. 4. Physics and Physical Technology, red. J. Needham, Cambridge 1971, s. 215, 368 n. Seria książek pod redakcją brytyjskiego historyka Josepha Needhama, wydawana od 1954 roku przez Cambridge University Press, liczy obecnie 27 tomów na temat dorobku chińskiej nauki i kultury. Prace Needhama stanowiły przeciwwagę dla europocentrycznego postrzegania źródeł wiedzy, czy postępu i zapoczątkowały dyskusję na temat wielokulturowych korzeni globalnej nauki.

46 Łacińska paremia: Sic utere tuo ut alienum non laedas [Używaj swojej własności w taki sposób, aby nie naruszyć cudzej] idealnie koreluje $\mathrm{z}$ analogiczną i centralną zasadą buddyzmu, w której alienum może oznaczać także przyszłe pokolenia. Por. Separate Opinion ..., s. 99; K.N. Jayatilleke, The principles of international law in Buddhist doctrine, ,Recueil des cours de l'Académie de droit international" 120, 1967, s. 558.

47 W. Geiger, The Mahavamsa or the Great Chronicle of Ceylon, Delhi 2014, rozdział 14, za: Separate Opinion...

48 „O great King, the birds of the air and the beasts have as equal a right to live and move about in any part of the land as thou. The land belongs to the people and all living beings; thou art only the guardian of it". Ibidem, s. 99.

49 „Powiernictwo" w doktrynie prawa common law jest stosunkiem prawnym pomiędzy właścicielem na mocy zasad słuszności (equitable ownership in property) oraz drugą osobą, która ma tytuł prawny do tej własności (legal ownership). Por. P. Stec, O anglosaskim i kontynentalnym rozumieniu powiernictwa, „Problemy Współczesnego Prawa Międzynarodowego, Europejskiego i Porównawczego" 1, 2003, s. 12-13. 
zobowiązane zarządzać tą własnością w najlepszym interesie narodu. Geneza tej doktryny sięga czasów rzymskich, była o niej mowa także w instytucjach Justyniana — ,Zgodnie z prawem naturalnym — powietrze, woda, zasoby mórz i wybrzeży są wspólnym dziedzictwem ludzkości" ${ }^{50}$.

W odróżnieniu od bogatej i wielowiekowej azjatyckiej tradycji zrównoważonego korzystania z zasobów przyrody, w Europie idea zrównoważonego rozwoju zaczęła się rozwijać dopiero w latach siedemdziesiątych XX wieku głównie w wyniku działalności organizacji międzynarodowych. Chociaż samo pojęcie „zrównoważony rozwój” pojawiło się znacznie wcześniej, na początku XIX wieku był on kojarzony z dobrymi praktykami leśnymi. Zasada, że wolno ścinać tyle drzew, ile może odrosnąć, aby nie zabrakło drewna dla potomnych, a jego dostępność trwale się nie zmniejszała, miała swoich zwolenników wśród naukowców zajmujących się naukami leśnymi w Niemczech, Austro-Węgrach, Szwajcarii, Francji, Rosji, Skandynawii i Wielkiej Brytanii, a także w ich koloniach. Niemiecki inżynier i badacz lasów Hans Carl von Carlowitz dla określenia tego procesu użył niemieckiego terminu Nachhaltigkeit ${ }^{51}$. Dyrektor Francuskiej Akademii Leśnej w Nancy, profesor Adolphe Parade, przetłumaczył w 1837 roku Nachhaltigkeit na production soutenu. Francuskie słowo soutenu ma łacińskie korzenie - od sustinere (zachowywać). Wszystkie te znaczenia obejmuje angielskie słowo: sustainable (zrównoważony) ${ }^{52}$.

\section{Internalizacja zasad zrównoważonego rozwoju w prawie Chińskiej Republiki Ludowej}

Budowanie reżimu totalitarnego przez komunistów i przeprowadzana przez nich gwałtowna industrializacja Chińskiej Republiki Ludowej w okresie zimnej wojny (1947-1991) nie sprzyjały realizacji celów nowożytnego międzynarodowego prawa ochrony środowiska ${ }^{53}$. W 1949 roku powstała Chińska Republika Ludowa, która była ogromnym, ale bardzo słabym i biednym krajem. Mao Zedong

50, „By the law of nature, these things are common to mankind the air, running water, the sea, and consequently the shores of the sea" - przeł. J.B.N. Res communis — laciński termin odpowiadający dzisiejszemu „wspólnemu dziedzictwu ludzkości”, por. Instytucje Justyniana, oprac. C. Kunderewicz, Warszawa 1986, księga 2.

${ }^{51}$ H.C. von Carlowitz, Sylvicultura oeconomica, oder haußwirthliche Nachricht und Naturmäßige Anweisung zur wilden Baum-Zucht, Leipzig 1713.

52 H. Izdebski, Zobowiazania wobec pokoleń przeszłych i przyszłych, [w:] Doktryny polityczno-prawne: fundamenty wspótczesnych państw, Warszawa 2017, s. 287-293; M. Kulesza, Zrównoważony rozwój z perspektywy historycznej, „Zeszyty Naukowe Instytutu Zarządzania i Marketingu im. J. Długosza w Częstochowie" 4, 2010, s. 9-10.

53 Za początek tej dziedziny przyjmuje się symbolicznie datę pierwszej konferencji ONZ poświęconej ochronie środowiska — tak zwanej Konferencji Sztokholmskiej z 1972 roku. Zapoczątkowała ona cykl konferencji poświęconych sprawom środowiska i zrównoważonego rozwoju. Ko- 
przedstawił propozycję „schińszczenia marksizmu” poprzez uwzględnienie specyficznych cech chińskiej kultury. Według jego ideologii, marksizm powinien zostać wzbogacony o elementy narodowe. $Z$ kolei uprzemysłowienie tak zacofanego i ubogiego kraju, jakim były Chiny, zmusiło Mao do przyjęcia zasady „opierania się na własnych siłach", a to oznaczało bezwzględną akumulację kapitału kosztem potrzeb ludności i środowiska naturalnego. Głosząc hasło o konieczności podboju i podporządkowania natury, Mao Zedong nie tylko zaognił konflikt z przyrodą, ale też usiłował zmienić rozumienie relacji człowieka z naturą, głęboko zakorzenione w chińskiej kulturze ${ }^{54}$. Mosty przerzucane nad sztucznie wyprostowanymi rzekami i tarasowanymi wzgórzami, wylesiane grunty i wyrobiska świadczyły o konsekwentnym i bezrefleksyjnym ujarzmianiu przyrody. Natura, choć nie była wrogiem sama w sobie, stanowiła przeszkodę na drodze industrialnej ${ }^{55}$ i kulturalnej rewolucji ${ }^{56}$. Intensywna deforestracja wzdłuż koryt rzek Żółtej i Jangcy przyczyniła się do wzmożonej erozji gleby, co z kolei stało się przyczyną częstych i dewastujących powodzi ${ }^{57}$. Bywały lata, że w wielkiej rzece Żółtej w związku z rozwojem przemysłu i intensyfikacją rolnictwa było tak mało wody, że można było ją przejść, zanurzając się zaledwie po kolana, a przypominała wtedy wielki ściek. Woda stała się zanieczyszczona i zaczęło jej brakować. Bardzo zanieczyściło się także powietrze, nasiliły procesy pustynnienia. W obliczu prawdziwej katastrofy ekologicznej, w 1971 roku Komunistyczna Partia Chin zainicjowała po raz pierwszy w historii chińską politykę ochrony środowiska. Teoretycznego uzasadnienia dla tych niezgodnych z maoistowskim imperatywem (,wzrost gospodarczy ponad wszystko") działań dostarczyła Dialektyka przyrody Fryderyka

lejna z nich odbyła się w Rio de Janeiro: 3-14 czerwca 1992 roku. Por. K. Wolfke, Międzynarodowe prawo środowiska (tworzenie i egzekwowanie), Wrocław 1979, s. 7.

54 C.R. McElwee, Environmental history of China, [w:] Environmental Law in China - Mitigating Risk and Ensuring Compliance, Oxford 2011, s. 1; J. Shapiro, Mao's War Against Nature: Politics and Environment in Revolutionary China, Cambridge-New York 2001.

55 Wielki Skok Naprzód — kampania 1958-1960 na rzecz radykalnego przyspieszenia rozwoju gospodarczego ChRL w wyniku, której produkcja przemysłowa miała wzrosnąć ponad sześciokrotnie, a rolnicza ponad dwukrotnie. Nieprzemyślane decyzje kierownictwa partyjno-państwowego, przykładowo: skierowanie w czasie żniw chłopów do wytopu stali w prymitywnych piecach, doprowadziły do gigantycznego marnotrawstwa i chaosu. Pierwsze lata realizacji Wielkiego Skoku spowodowały gigantyczny kryzys gospodarczy i śmierć głodową 46 milionów ludzi, por. J. Fenby, Wielki Skok w przepaść, [w:] idem, Chiny. Upadek i narodziny wielkiej potęgi, Kraków 2009, s. $541-564$.

${ }^{56}$ Wielka Proletariacka Rewolucja Kulturalna 1966-1976 - Kampania Mao przeciwko „Zwolennikom kapitalizmu” w kierownictwie partii. Prześladowaniami objęto kilkadziesiąt milionów ludzi, kilka milionów zamordowano, terenowy aparat partyjny uległ rozproszeniu. W chaosie „rewolucji kulturalnej” spadła produkcja przemysłowa i rolna, wiele zabytków kultury chińskiej zostało zniszczonych - por. J. Fenby, Uczta krytyki, [w:] idem, Chiny. Upadek..., s. 597-665.

57 M. Chengrui, H.E. Dregne, Silt and the future development of China's Yellow River, „Geographical Journal” 167, 2001, nr 1, s. 12-13; G. Leung, Reclamation and sediment control in the Middle Yellow River Valley, „Water International” 21, 1996, s. 12-19; E. Benvenisti, op. cit., s. 282 n. 
Engelsa ${ }^{58}$. Utworzono rządowy departament ochrony środowiska, który w przyszłości został zastąpiony przez Narodową Komisję Rozwoju i Reform. W 1998 roku, po serii katastrofalnych powodzi, powołano w Chinach Narodową Agencję do Spraw Ochrony Środowiska na poziomie ministerialnym (State Environmental Protection Administration, SEPA) $)^{59}$.

W tym czasie prawnomiędzynarodowy, zinstytucjonalizowany ruch na rzecz zrównoważonego rozwoju kształtował się pod egidą Organizacji Narodów Zjednoczonych, w której Chiny notabene odgrywały znaczącą rolę. Republika Chińska Czang Kaj-szeka była sygnatariuszem Karty Narodów Zjednoczonych ${ }^{60}$ i do 1971 roku reprezentowała Chiny jako stałego członka Rady Bezpieczeństwa. Od tego czasu Chińska Republika Ludowa (ChRL) Mao Zedonga zajęła miejsce Republiki Chińskiej w ONZ, a przedstawiciele ChRL zastąpili swych poprzedników we wszystkich organach ONZ ${ }^{61}$. Jako sygnatariusz Karty Narodów Zjednoczonych ChRL była związana politycznymi, gospodarczymi i społecznymi celami ONZ ${ }^{62}$.

Na I Szczyt Ziemi w Sztokholmie w 1972 roku przybyła liczna chińska delegacja. Już w czasie przygotowań do konferencji poglądy na temat rozwoju i ochrony środowiska poróżniły rozwinięte państwa Północy i rozwijające się państwa

58 F. Engels, Dialektyka przyrody, przeł. T. Zabłudowski, Warszawa 1953; C.R. McElwee, op. cit., s. $21 \mathrm{n}$.

59 W 2008 roku SEPA została przekształcona w Ministerstwo ds. Ochrony Środowiska ChRL, obecnie, od 2018 roku: Ministerstwo Ekologii i Ochrony Środowiska ChRL: http://english.mee.gov. $\mathrm{cn} / \mathrm{w}$ ramach rządu centralnego - Rady Państwowej. Por. J. Rowiński, W. Jakóbiec, System konstytucyjny Chińskiej Republiki Ludowej, Warszawa 2006, s. 56-58. ChRL od 1946 roku do dzisiaj stała się stroną ponad 50 umów międzynarodowych i protokołów z obszaru ochrony środowiska. Niezmiennie problemem pozostaje implementacja ich założeń na poziomie lokalnym.

60 Podpisana w San Francisco 26 czerwca 1945 roku, powołała do życia Organizację Narodów Zjednoczonych, http://libr.sejm.gov.pl/tek01/txt/onz/1945.html. Karta Narodów Zjednoczonych wraz ze statutem Międzynarodowego Trybunatu Sprawiedliwości, oprac. L. Ehrlich, Kraków 1946; B. Fassbender, The United Nations Charter as the Constitution of the International Community, Leiden 2009.

61 Do 1971 Republika Chińska na Tajwanie, dzięki poparciu USA i ich sojuszników, była reprezentantem całych Chin w ONZ i miała miejsce w Radzie Bezpieczeństwa, mimo że realnie sprawowała władzę tylko nad Tajwanem i pobliskimi wyspami. Państwa bloku komunistycznego za jedynego reprezentanta Chin konsekwentnie uznawały rząd w Pekinie i próbowały usunąć Republikę Chińską z ONZ. Udało się to dopiero, gdy USA, dążąc do poprawy stosunków z Pekinem, oświadczyły, że nie będą się sprzeciwiać przyjęciu ChRL do ONZ. Przyjęta na wniosek Albanii Rezolucja 2758 szła jednak znacznie dalej, usuwając Republikę Chińską i zastępując ją we wszystkich organach ONZ przedstawicielami ChRL. Por. A/RES/2758(XXVI), Restoration of the lawful rights of the People's Republic of China in the United Nations, UN General Assembly Resolution 2758, 25.10.1971.

62 Kartą Narodów Zjednoczonych inspirowanych było Pięć zasad pokojowej egzystencji z 1954 roku. „The Prime Minister, Zhou En-lai clearly stated: »The Chinese people have consistently supported the purposes and principles of the UN Charter «". Collection of Documents Relating to the Foreign Relations, t. 3. (1954-1955), Beijing, za: W. Tieya, International Law in China, „Hague Recuil", 221, 1990, s. 219-225. 
Południa ${ }^{63}$. Chińczycy zajęli twarde stanowisko, że globalna polityka ochrony środowiska uwzględniała wyłącznie interesy państw rozwiniętych, które próbowały narzucić krajom rozwijającym się zbyt ambitne standardy ochrony środowiska, stojące w sprzeczności z ich nieskrępowanym rozwojem gospodarczym ${ }^{64}$. Ostatecznie na spotkaniu panelowym w Founex w Szwajcarii (4-12 czerwca 1971 roku) 27 ekspertów pod przewodnictwem Maurice’a Stronga ustaliło, że państwa rozwijające się, w tym Chiny, będą kreować swoją politykę ekologiczną zgodnie $\mathrm{z}$ ich narodowymi potrzebami i interesami. Przyjęcie tego stanowiska spowodowało, że państwa te ostatecznie nie zbojkotowały konferencji sztokholmskiej ${ }^{65} .16$ czerwca 1972 roku konferencja przyjęła Deklarację Konferencji Narodów Zjednoczonych w sprawie naturalnego środowiska człowieka, tak zwaną Deklarację Sztokholmską ${ }^{66}$. Zwrócono tam uwagę na sytuację państw rozwijających się, w których problemy środowiskowe były ściśle związane z opóźnieniami w ich rozwoju. Podkreślono, że „należy [...] rozwijać odpowiednią politykę w odniesieniu do środowiska, także w ramach współpracy międzynarodowej, uwzględniając warunki i szczególne potrzeby państw rozwijających się". Wskazano też konieczność przyjęcia zintegrowanego i skoordynowanego podejścia do rozwoju, by był on zgodny z potrzebami ochrony i ulepszania środowiska. Za istotny instrument synchronizujący potrzeby rozwoju i ochrony środowiska uznano racjonalne planowanie, które powinno być także stosowane w odniesieniu do ludzkich osiedli i procesów urbanizacyjnych. Właściwa polityka demograficzna powinna była uwzględniać specyfikę regionów i prawa człowieka.

W 1987 roku Światowa Komisja do Spraw Środowiska i Rozwoju (World Commission on Environment and Development - $\mathrm{WCED}^{67}$ ), kierowana wówczas przez Gro Harlem Brundtland, przyjęła Raport Brundtland - przełomowy dokument dotyczący ochrony środowiska i rozwoju zatytułowany Nasza wspólna przyszłość. Koncepcja zrównoważonego rozwoju stała się następnie myślą przewodnią Deklaracji z Rio w sprawie Środowiska i Rozwoju z 1992 roku $^{68}$, która zwieńczyła drugą wielką międzynarodową konferencję w sprawie ochrony

${ }^{63} \mathrm{~W}$ czasach zimnej wojny demokratyczne kraje uprzemysłowione nazywano Pierwszym Światem, Drugi Świat stanowiły komunistyczne kraje uprzemysłowione (w tym ZSRR, Chiny), a Trzeci Świat - kraje rozwijające się.

${ }^{64}$ R. Clay, China: The next environmental super power, „Environmental Health Perspectives" 110, 2002, nr 9, s. 524-527.

65 G. Handl, Declaration of the United Nations Conference on the human environment (Stokholm Declaration), 1972 and the Rio Declaration on Environment and Development, 1992, United Nations Audiovisual Library of International Law, 2012, www.un.org/law/avl (dostęp: 24.06.2021).

66 Stockholm Declaration on the Human Environment, [w:] Report of the United Nations Conference on the Human Environment, UN Doc.A/CONF.48/14, at 2 and Corr.1, 1972.

67 Powołana w 1983 roku w celu przeciwdziałania przez ONZ gwałtownemu pogarszaniu się stanu środowiska naturalnego, por. Resolution adopted by the General Assembly 38/161, Process of preparation of the Environmental Perspective to the Year 2000 and Beyond, A/RES/38/161.

68 Rio Declaration on Environment and Development, in Report of the United Nations Conference on Environment and Development, UN Doc. A/CONF.151/26 (t. 1), 12.08.1992, Annex I. 
środowiska w Rio de Janeiro w 1992 roku (II Szczyt Ziemi). Deklaracja z Rio miała duży wpływ na kształtowanie się zwyczaju międzynarodowego i późniejszych uregulowań traktatowych dotyczących zrównoważonego rozwoju. Jej postanowienia zostały skonkretyzowane w programie działań na rzecz środowiska i rozwoju zawartym w Agendzie $21^{69}$. Podczas Konferencji w Rio de Janeiro otwarto też do podpisu Ramową Konwencję NZ w sprawie zmian klimatu z 9 maja 1992 roku $^{70}$. Jako główny cel konwencji wskazano doprowadzenie do ustabilizowania koncentracji gazów cieplarnianych w atmosferze na takim poziomie, który zapobiegałby niebezpiecznej ingerencji o charakterze antropogenicznym w system klimatyczny na świecie. Państwa-strony zobowiązały się do ochrony tego systemu dla obecnych i przyszłych pokoleń oraz uwzględniania w podejmowanych działaniach specyficznych potrzeb i szczególnej sytuacji państw rozwijających się. Państwa powinny podejmować środki zmierzające do zapobiegania i minimalizowania przyczyn zmian klimatu i łagodzenia ich negatywnych skutków. Powinny też promować zrównoważony rozwój i współdziałać na rzecz jego wdrożenia ${ }^{71}$. O ile pod koniec lat sześćdziesiątych XX wieku problemami ochrony środowiska żyły społeczeństwa państw zachodnich, to w wyniku intensyfikacji działań proekologicznych na forum międzynarodowym pod koniec lat osiemdziesiątych i dziewięćdziesiątych interesował się już nimi cały świat.

Bezpośrednim następstwem zaangażowania Chin w Konferencję Sztokholmską w 1972 roku było przyjęcie pierwszego chińskiego prawa o ochronie środowiska (Environmental Protection Law) w 1979 roku. Drugi wzrost zainteresowania ustawodawcy chińskiego ochroną środowiska przypadł na rok 1993 i był bezpośrednim skutkiem konferencji w Rio. Wtedy to przyjęto szereg szczegółowych ustaw środowiskowych i zrewidowano istniejące ${ }^{72}$. Do 2014 roku Parlament Chińskiej

69 W agendzie 21 podkreślono, że w jej wdrażaniu powinny uczestniczyć państwa i organizacje międzynarodowe. Sprawy ochrony środowiska i rozwoju należy bowiem podejmować w zintegrowany sposób na płaszczyźnie krajowej, podregionalnej i regionalnej, a także ogólnoświatowej, zwłaszcza w ramach ONZ. Nowe zadania trzeba powierzyć organom ONZ i funkcjonującym w jej ramach programom - UNEP (United Nations Environment Programme) i UNDP (United Nations Development Programme). Postanowiono też utworzyć Komisję do spraw Zrównoważonego Rozwoju oraz sekretariat pomocniczy. W procesie tworzenia prawa międzynarodowego w zakresie zrównoważonego rozwoju powinny uczestniczyć wszystkie państwa, również państwa rozwijające się, a spory międzynarodowe $\mathrm{w}$ tej dziedzinie powinny być rozwiązywane środkami pokojowymi, zgodnie z Kartą NZ; https://www.un.org/esa/dsd/agenda21/res_agenda21_00.shtml (dostęp: 28.06.2021).

${ }^{70}$ United Nations Framework Convention on Climate Change, 9 May 1992, United Nations, Treaty Series, t. 1771, s. 107.

71 Na temat instytucjonalizacji działań na rzecz środowiska w ramach ONZ zob. G. Nagtzaam, E. van Hook, D. Guilfoyle, International Environmental Law, London-New York 2020, s. 15 n.

72 Z. Mu, S. Bu, B. Xue, Environmental legislation in China: Achievements, challenges and trends, „Sustainability” 6, 2014, s. 8969 n.; B. Zhang et al., A new environmental protection law, many old problems? Challenges to environmental governance in China, ,Journal of Environmental Law" 28, 2016, s. 326 n. 
Republiki Ludowej przyjął ponad 30 ustaw dotyczących ochrony środowiska. Trzeba zatem zauważyć, że w odpowiedzi na zobowiązania międzynarodowe i postępujący proces degradacji środowiska, w ciągu 35 lat od zera powstało w Chinach korelujące ze standardami międzynarodowymi kompleksowe ustawodawstwo środowiskowe. Przedstawiciele doktryny, także chińskiej, wskazywali jednak na jego niską efektywność i minimalny poziom egzekucji. Z tego powodu w 2014 roku, po trzech latach prac i konsultacji ${ }^{73}$, znacząco zrewidowano prawo o ochronie środowiska z 1972 roku $^{74}$. Jednym z największych osiągnięć tej nowelizacji było wyartykułowanie tam zasad ogólnych międzynarodowego prawa ochrony środowiska, w tym zasad zrównoważonego rozwoju. Artykuł 4 chińskiego Prawa Ochrony Środowiska w nowej wersji stanowi: „Ochrona środowiska jest podstawową polityką państwa.

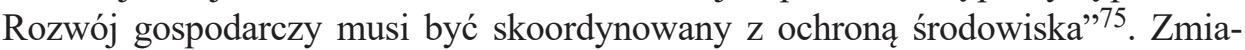
ny przyjęte w ramach tego przepisu są przełomowe, zważywszy że w poprzedniej wersji z 1989 roku wyrażał on dokładnie przeciwną regułę: ,interes gospodarczy ponad wszystko". Trzeba także zauważyć, że pojęcie zrównoważonego rozwoju dotychczas w chińskim ustawodawstwie środowiskowym pojawiało się sporadycznie i nie było eksponowane jako zasada prawa ${ }^{76}$. W nowym artykule 5 chińskiego prawa o ochronie środowiska znalazły się zasady, które w doktrynie europejskiego prawa ochrony środowiska uznaje się za elementy konstytutywne zrównoważonego rozwoju (sub-principles) ${ }^{77}$. Mowa tu przede wszystkim o horyzontalnej zasadzie integracji wymogów ochrony środowiska z pozostałymi politykami oraz o zasadzie prewencji. Dodatkowo przepis ten zawiera zasadę partycypacji społecznej w podejmowaniu decyzji środowiskowych oraz zasadę ,zanieczyszczający płaci”. Szeroko zakrojone zmiany legislacyjne, nie tylko na poziomie zasad ogólnych, ale także przepisów szczegółowych, budzą nadzieje na realizację celów chińskiego prawa o ochronie środowiska w nowej odsłonie. Zamierzenia są jednak ambitne, bo wraz ze wspomnianą nowelizacją kierownictwo partyjne Chińskiej Republiki Ludowej ogłosiło początek budowy „cywilizacji ekologicznej”78.

\section{Podsumowanie}

W wymiarze ekologicznym Chiny to pełne sprzeczności autorytarne mocarstwo o ogromnym wpływie na losy współczesnego świata. Jednoczesnie chińska

73 L. Zhang, G. He, A.P.J. Mol, China's new environmental protection law: A game changer?, „Environmental Development” 13, 2015, s. 1-3.

${ }^{74}$ China's NPC adopts revised Environmental Protection Law, http://ca.china-embassy.org/ eng/zt/economy123/t1149908.htm (dostęp: 28.06.2021).

75 L. Zhang, G. He, A.P.J. Mol, op. cit., s. 2.

$76 \mathrm{Mu}$ Z., Bu S., Xue B., op. cit., s. 8971.

77 Por.: L.A. Avilés, op. cit., s. 30-31; S.R.W. van Hees, op. cit., s. 66-71.

78 A.J. Liu, Ecological civilization and China's environmental legislation, „Chinese Journal of Population, Resources and Environment" 14, 2004, s. 36-39. 
tradycja prawna i wielkie systemy filozoficzno-religijne Azji Południowo-Wschodniej — taoizm, konfucjanizm i buddyzm — jako materialne źródła ochrony przyrody mają wiele do zaoferowania. Nowoczesne podejście do prawa międzynarodowego podkreśla powszechny zasięg tego prawa i jego dążenie do reprezentowania głównych światowych form cywilizacji i podstawowych systemów prawnych. Z kolei artykuł 38 statutu MTS, zawierający katalog źródeł prawa międzynarodowego, zostawia otwarte drzwi dla ,zasad ogólnych uznanych przez narody cywilizowane". Zrównoważony rozwój jako jedna z najbardziej starożytnych idei ludzkości z pewnością do bycia taką zasadą aspiruje.

Wydawać by się mogło, że im większa zbieżność kultury i tradycji prawnej z zasadą prawa, która ma być uznana, tym większe szanse, że zasada ta zostanie włączona w system prawny ${ }^{79}$. Pozostaje pytanie, w jakim stopniu trudna historia Chin XX wieku, totalitaryzm i maoistowski antytradycjonalizm przekreśliły wcześniejszy dorobek tej wielowiekowej cywilizacji. Dzisiaj internalizacja prawnomiędzynarodowych zasad zrównoważonego rozwoju we współczesnym prawie chińskim przebiega wolno, chociaż postępy są widoczne. Autorzy chińscy ze spokojem i słusznie zauważają, że jeszcze wiele pozostało do zrobienia ${ }^{80}$.

\section{Bibliografia}

Albińska M., Karl August Wittfogel: badacz tradycji władzy totalnej w dziejach cywilizacji, Toruń 2006.

Alford W.P., Yuanyuan S., Limits of law in addressing China's environmental dilemma, „Stanford Environmental Law Journal” 12, 1997, nr 1.

Antonowicz L., Podręcznik prawa międzynarodowego, Warszawa 1998.

Avilés L.A., Sustainable development and the legal protection of the environment in Europe, „Sustainable Development Law \& Policy" 12, 2012, nr 3.

Bachner B., Regulating pollution in the People's Republic of China: An analysis of the enforcement of environmental law, „Colorado Journal of International Environmental Law and Policy” 7, $1996, \mathrm{nr} 2$.

Bao M., Environmental history in China, „Environment and History” 10, 2004.

Bazylińska-Nagler J., Right to clean environment - a warrant of sustainable development?, „Ekonomia - Wroclaw Economic Review"24, 2018, nr 3.

Benvenisti E., Asian traditions and contemporary international law on the management of natural resources, „Chinese Journal of International Law” 7, 2008.

Beyer S., Environmental law and policy in the People's Republic of China, „Chinese Journal of International Law" 5, 2006.

79 Usus consuetudo (przyzwyczajenie) oraz opinio iuris sive necessitates jako elementy konstytutywne zwyczaju międzynarodowego. Przyzwyczajenie i przekonanie o mocy wiążącej kształtują normy zwyczajowe prawa międzynarodowego, por. A. Cassese, International Law, Oxford 2001, s. 155 n.; R. Macrory, Principles of European Environmental Law, Groningen 2004, s. 22.

80 Z. Mu, S. Bu, B. Xue, op. cit., s. 8968 n.; J. Wang, Thirty years rule of environmental law in China: Retrospect and reassessment, , Journal of China University of Geosciences” 9, 2009, s. 3-9; Q.J. Li, Chinese environmental legislation assessment: Sustainable development and innovation, „Chinese Journal of Population, Resources and Environment” 11, 2001, s. 23-28. 
Bruntland G.H., Our Common Future, Oxford 1987.

Carlowitz H.C. von, Sylvicultura oeconomica, oder haußwirthliche Nachricht und Naturmäßige Anweisung zur wilden Baum-Zucht, Leipzig 1713.

Cassese A., International Law, Oxford 2001.

Cepelka C., The dispute over the Gabčikovo-Nagymaros systems of locks is drawing to a close, „Polish Yearbook of International Law” 20, 1993, s. 63-74.

Chengrui M., Dregne H.E., Silt and the future development of China's Yellow River, „Geographical Journal" 167, 2001, nr 1.

China: Confucian Tradition - Towards the New Century, red. A.W. Jelonek, B.S. Zemanek, Kraków 2008.

Chiny, red. K. Gawlikowski, E. Potocka, Toruń 2001.

Chiny: rozwój społeczeństwa i państwa na przełomie XX i XXI wieku, red. K. Gawlikowski, K. Tomala, Warszawa 2002.

Clay R., China: The next environmental super power, „Environmental Health Perspectives” 110, 2002, nr 9.

Cordonier Segger M.C., Khalfan A., Sustainable Development Law: Principles, Practices, and Prospects, Oxford 2011.

Dargas-Draganik M., Idee i zasady konstytucyjne chińskiego porządku prawnego, Warszawa 2017.

Dresner S., The Principles of Sustainability, London 2008.

Economy E.C., Environmental enforcement in China, [w:] China's Environment and the Challenge of Sustainable Development, red, K.E. Day, London-New York 2005.

Ehrlich L., Prawo międzynarodowe, Warszawa 1958.

Elvin M., The environmental legacy of imperial China, „China Quarterly” 156, 1999.

Elvin M., The Retreat of the Elephants: An Environmental History of China, Yale 2006.

Encyklopedia madrości Wschodu: buddyzm, hinduizm, taoizm, zen, red. I. Fischer Schreiber, przeł. M.J. Künstler, Warszawa 1997.

Engels F., Dialektyka przyrody, przeł. T. Zabłudowski, Warszawa 1953.

Fassbender B., The United Nations Charter as the Constitution of the International Community, Leiden 2009.

Fenby J., Chiny. Upadek i narodziny wielkiej potęgi, Kraków 2009.

Fong B., Hsu C., Constitutional protection of a sustainable environment in the Hong Kong special administrative region, „Journal of Environmental Law” 2, 2016.

Fulton S., Benjamin A., Foundations of sustainability, „The Environmental Forum” 28, 2011.

Gawlikowski K., Konfucjański model państwa w Chinach, Warszawa 2009.

Gawlikowski K., Nowa batalia o Konfucjusza, Warszawa 1976.

Handl G., Declaration of the United Nations Conference on the human environment (Stokholm Declaration), 1972 and the Rio Declaration on Environment and Development, 1992, United Nations Audiovisual Library of International Law, 2012, www.un.org/law/avl.

Hees S.R.W. van, Sustainable development in the EU: Redefining and operationalizing the concept, „Utrecht Law Review” 10, 2014, nr 2.

Hou W., Reflections on Chinese traditional views of nature, „Environmental History” 2, 1997.

Hsu I.C.Y., China's Entrance into the Family of Nations, Harvard 1960.

Humphreys M., Sustainable Development in the European Union: A General Principle, LondonNew York 2020.

Huntington S.P., Democracy's third wave, „Journal of Democracy” 2, 1991, nr 2.

Intergenerational Justice in Sustainable Development Treaty Implementation: Advancing Future Generations Rights through National Institutions (Treaty Implementation for Sustainable Development), red. M.C. Cordonier Segger, M. Szabo, A. Harrington, Cambridge 2021.

Iriye K., The principles of international law in the light of Confucian doctrine, „Recueil des Cours” 120, 1967.

Studia nad Autorytaryzmem i Totalitaryzmem 43, nr 2, 2021

(C) for this edition by CNS 
Izdebski H., Zobowiazania wobec pokoleń przesztych i przyszłych, [w:] Doktryny polityczno-prawne: fundamenty wspótczesnych państw, Warszawa 2017.

Jayatilleke K.N., The principles of international law in Buddhist doctrine, „Recueil des cours de l'Académie de droit international" 120, 1967.

Jelonek A.W., Confucianism-Asian values and liberal democracy, [w:] China: Confucian Tradition - Towards the New Century, red. A.W. Jelonek, B.S. Zemanek, Kraków 2008.

Karta Narodów Zjednoczonych wraz ze statutem Międzynarodowego Trybunatu Sprawiedliwości, oprac. L. Ehrlich, Kraków 1946.

Kenig-Witkowska M., The concept of sustainable development in the European Union policy and law, „Journal of Comparative Urban Law and Policy” 1, 2017, nr 1.

Konfucjusz, Dialogi, przeł. K. Czyżewska-Madajewicz, M.J. Kunstler, Z. Tłumski, Wrocław 1976.

Konwencja wiedeńska o prawie umów międzynarodowych, przeł. i oprac. S.E. Nahlik, Warszawa 1971.

Kulesza M., Zrównoważony rozwój z perspektywy historycznej, „Zeszyty Naukowe Instytutu Zarządzania i Marketingu im. J. Długosza w Częstochowie” 4, 2010.

Lee E.Y.J., Early development of modern international law in East Asia - with special reference to China, Japan and Korea, „Journal of the History of International Law” 4, 2002.

Leung G., Reclamation and sediment control in the Middle Yellow River Valley, „Water International" 21, 1996.

Li Q.J., Chinese environmental legislation assessment: Sustainable development and innovation, „Chinese Journal of Population, Resources and Environment” 11, 2001.

Liu A.J., Ecological civilization and China's environmental legislation, „Chinese Journal of Population, Resources and Environment" 14, 2004.

Macrory R., Principles of European Environmental Law, Groningen 2004.

McElwee C.R., Environmental history of China, [w:] Environmental Law in China - Mitigating Risk and Ensuring Compliance, Oxford 2011.

$\mathrm{Mu} \mathrm{Z} ., \mathrm{Bu}$ S., Xue B., Environmental legislation in China: Achievements, challenges and trends, „Sustainability” 6, 2014.

Nagtzaam G., Hook E. van, Guilfoyle D., International Environmental Law. A Case Study Analysis, London 2020.

Science and Civilization in China, t. 4. Physics and Physical Technology, red. J. Needham, Cambridge 1971.

Pajor J., Wielka Brytania wobec kształtowania się amerykańskiej polityki ,,Otwartych drzwi” w Chinach (1898-1900), „Acta Universitatis Lodziensis Folia Historica” 89, 2012.

Peretiatkowicz A., Ogólne zasady prawa jako źródło prawa międzynarodowego a tendencje kosmopolityczne, Poznań 1956.

Report of the World Commission on Environment and Development, "Our Common Future”, 4.08.1987 (A/42/427, Annex), https://sustainabledevelopment.un.org/content/documents/5987our-commonfuture.pdf.

Rojek W., Ekspansja mocarstw w Chinach i jej wplyw na rozwój stosunków międzynarodowych w latach 1895-1914, Kraków 1990.

Rowiński J., Jakóbiec W., Parlament Chińskiej Republiki Ludowej, Warszawa 2008.

Rowiński J., Jakóbiec W., System konstytucyjny Chińskiej Republiki Ludowej, Warszawa 2006.

Shall C., Public interest litigation concerning environmental matters before human rights courts: A promising future concept, ,Journal of Environmental Law” 20, 2008, nr 3.

Shapiro J., Mao's War Against Nature: Politics and Environment in Revolutionary China, Cambridge-New York 2001.

Shaw M.N., Prawo międzynarodowe, Warszawa 2006.

Singh N., The distinguishing characteristics of the concept of the Law of Nations as it developed in ancient India, [w:] Liber Amicorum for Lord Wilberforce, red. A. Bos, I. Brownlie, Oxford 1987. 
Stownik historii doktryn politycznych, red. M. Jaskólski, t. 1-6, Warszawa 2007.

Stec P., O anglosaskim i kontynentalnym rozumieniu powiernictwa, „Problemy Współczesnego Prawa Międzynarodowego, Europejskiego i Porównawczego" 1, 2003.

Stępień M., Chińskie marzenie o konstytucjonalizmie, Kraków 2015.

Stockholm Declaration on the Human Environment, [w:] Report of the United Nations Conference on the Human Environment, UN Doc.A/CONF.48/14, at 2 and Corr.1, 1972.

Sustainable Development Principles in the decisions of International Courts and Tribunals 19922012, red. M.C. Cordonier Segger, C.G. Weeramantry, New York 2017.

Szacki J., Tradycja, Warszawa 2011.

Tieya W., International Law in China, „Hague Recuil” 221, 1990.

Treaties and Agreements with and Concerning China 1894-1919, red. J.V.A. MacMurray, t. 1. Manchu Period (1894-1911), t. 2. Republican period (1912-1919), Oxford-New York 1921.

The Vienna Convention on the Law of Treaties: A Commentary, red. O. Dörr, K. Schmalenbach, Berlin 2012.

Villiger M., Commentary on the 1969 Vienna Convention on the Law of Treaties, Leiden 2009.

Wang J., Thirty years rule of environmental law in China: Retrospect and reassessment, „Journal of China University of Geosciences" 9, 2009.

Weeramantry C.G., Tread Lightly on the Earth. Religion, the Environment and the Human Future, Pannipitiya 2014.

Wittfogel K.A., Władza totalna: studium porównawcze despotyzmu wschodniego, Toruń 2004.

Wolfke K., Custom in Present International Law, Wroclaw 1964.

Wolfke K., Międzynarodowe prawo środowiska (tworzenie i egzekwowanie), Wrocław 1979.

Xi W., People's Republic of China, [w:] The Oxford Handbook of Comparative Environmental Law, red. E. Lees, J.E. Viñuales, Oxford 2019.

Zartner D., East Asian legal tradition, [w:] Courts, Codes, and Custom: Legal Tradition and State Policy Toward International Human Rights and Environmental Law, Oxford 2014.

Zhang B., Cao C., Gu J., Liu T., A new environmental protection law, many old problems? Challenges to environmental governance in China, „Journal of Environmental Law” 28, 2016.

Zhang L., He G., Mol A.P.J., China's new environmental protection law: A game changer? „Environmental Development" 13, 2015.

Zhu X., Wu K., Public participation in China's environmental lawmaking: In pursuit of better environmental democracy, ,Journal of Environmental Law” 29, 2017. 